\title{
History of Complex Identity Research
}

\author{
Yulia S. Zamaraeva and Natalia P. Koptseva* \\ Siberian Federal University \\ Krasnoyarsk, Russian Federation
}

Received 28.05.2020, received in revised form 04.06.2020, accepted 06.07.2020

\begin{abstract}
The article reveals conceptual problems of the formation of the concept of "complex identity" in modern humanities based on the analysis of foreign and Russian studies. In scientific history, the conceptual definition of the notion emerged in the last third of the $20^{\text {th }}$ century in sociology and social psychology, however, since the beginning of the $21^{\text {st }}$ century it received further development due to the interdisciplinary research, which allowed scientists to identify complex forms of identity in a dynamically developing world. At the beginning of the $21^{\text {st }}$ century, the interest in identity as a cultural problem increased and it became necessary to study it in the context of modern culture and intercultural relations. Culturological problems allow us to combine existing ideas into a conceptual definition of the concept of "complex identity" and to prioritize research in accordance with modern socio-cultural relations.
\end{abstract}

Keywords: theory of social identity, complex identity, nature of the complexity of social identity.

Research area: theory and history of culture.

Citation: Zamaraeva, Yu.S., Koptseva, N.P. (2020). History of complex identity research. J. Sib. Fed. Univ. Humanit. Soc. Sci., 13(7), 1216-1229. DOI: 10.17516/1997-1370-0637.

(C) Siberian Federal University. All rights reserved

* Corresponding author E-mail address: rybka08@bk.ru, decanka@mail.ru ORCID: 0000-0003-1299-6741 (Zamaraeva); 0000-0003-3910-7991(Koptseva) 


\section{Introduction}

The concept of "social identity" began to develop in foreign science in the 1970's in connection with the study of intra-group relations, group processes and inter-group relations associated with the persecution of various ethnic and social groups (Hornsey, 2008). Muzafer Sherif and Carolyn Wood Sherif, who conducted a field study titled "Robber's Cave" in the Sherif camp in 1954, became one of the first researchers in the study of intergroup hostility. The experiment was based on the formation of intergroup relations between two in-groups of adolescents, the competitive phase with an exacerbation of intergroup hostility and the integration stage with the attainment of intergroup cooperation. As a result of the study, scientists recorded a number of features: 1) individual differences are not a significant factor for the occurrence of intergroup conflict; 2) a hostile and aggressive attitude, negative behaviour towards an external group (out-group) arises as a result of a competition for resources that only one group can obtain; 3 ) the integration interrelation arises only with the support of positive intergroup relations, in the presence of higher goals that contribute to a united, joint action. Thanks to the Sherifs' experiment, the concept of "social group" is fixed in social psychology in the field of interpersonal processes and begins to develop in two theories: D.T. Campbell's realistic group conflict theory («Realistic conflict theory» (Campbell, 1965)), which studies the phenomenon of intergroup hostility, and the social identity theory of intergroup behaviour («Social identity theory» (Tajfel, 1974) developed by Polish social psychologist Henri Tajfel and his student, the British social psychologist, John Charles Turner, and the self-categorization theory («Self-categorization theory» (Turner et al., 1987) subsequently developed by John Turner and his colleagues as concomitant to the social identity theory. The last two theories together are known as the social identity approach.

During the 1970's, checking the results of the Sherif's field experiment, H. Tajfel and J. Turner conduct their own experimental studies of intergroup relations and conclude that through intergroup interaction, another level of self-esteem is activated as a set of representations of oneself and others as members of a particular group, including emotional and the estimated consequences of this group membership. The idea of one's group (in-group), but not an external group (out-group), is dictated by the individual's desire for a positive and safe self-esteem. At the same time, the reality of one's group arises at the border of a positive comparison with the characteristics of the external group.

The social identity theory is applied to the study of collective intra-group identities (Tajfel, 1978; Tajfel \& Turner, 1979; Tajfel, 1982). The basis for theoretical research is a hypothesis that individuals determine their personal identity in relation to social groups, and social identity "works" to protect and support self-identification. Due to social identity, individuals have a collective, impersonal identification that is based on the realization of their belonging to the group (Turner et., 1987). Henry Tajfel confirmed his idea that the social world is recognized by an individual as divided into different groups. An individual has intrinsic motivation and a tendency to classify himself into one or several ingroups, creating part of his identity on the basis of belonging to this group and establishing boundaries with other groups. In society, an individual classifies (organizes) the social environment into various social groups and categorizes himself within certain groups (by status, age, gender, profession, faith, education, etc.) in order to better determine his position in society. The more similarities (identifications) an individual discovers with a particular category, the more value the group has for him.

The social identity theory has become an explanatory paradigm in the study of social behaviour in terms of intergroup racial and ethnic discrimination, a hostile attitude between groups of unequal status. Developing the theory of social identity, Henry Tajfel and J. Turner gradually redefined the opinion of sociologists towards understanding of intergroup relations as a process that is controlled by "social-structural variables": intergroup behaviour is largely determined by people's subjective ideas of where they are in the hierarchy of sta- 
tus, power, and their ideas of the permeability, stability and legitimacy of this hierarchy. However, scientists understood the impossibility of studying intergroup relations or a high-level intergroup conflict through the analysis of a minimal group, and recognized that there was a gap between a theoretical and methodological approach to the study of social identity.

In the 1990's, in the framework of the cognitive paradigm of social psychology and cross-cultural psychology, scientists have developed a construct of complex social identity to understand the processes of social categorization and to answer the question "how does an individual interact with representatives of other groups"? The construct allows us to analyse the structure of a person's multiple social identity, a combination of this multiplicity in the content of social categories of a person. Social identity can be identified on the basis of an analysis of the subjective ideas of the individual about the interconnection of his group identities and reflects the degree of perceived similarity between them (intersection). The degree of complexity of social identity increases the more dissimilar various categories are recognized by a person. And vice versa, the more similar the in-groups are recognized by a person, the simpler social identity he possesses. The complexity of social identity depends on social perception (on categorization), on the awareness and acceptance of differences between groups (in-groups and out-groups). For example, Philip Tetlock, through his research in the field of social psychology, discovers levels of integrative complexity that require laborious cognitive strategies and resources (Tetlock, 1983, 1986). Tetlock studies a model of pluralism of values that are often controversial, which provokes people to think in integrally complex ways. Thus, the scientist makes a description of the cognitive structure as a process in order to test the basic hypotheses about a complex identity model.

\section{Research methods}

The basis of the study is the method of review analysis, which allows us to trace the reasons for the emergence and the line of general scientific development of the concept of "complex identity" in the $20^{\text {th }}-21^{\text {st }}$ centuries. This method is aimed at a theoretical analysis of the concept and analysis of the problems of complex identity in the interdisciplinary field of the humanities. The result of the application of the method will be the identification of the spectrum of existing approaches and concepts in foreign and Russian studies of the $20^{\text {th }}$ early $21^{\text {st }}$ centuries, and the formation of conceptual provisions on complex identity as a socio-cultural phenomenon.

\section{Discussion on the nature of the complexity of social identity in modern humanities}

The concept of "complex identity" was further developed in the theories of categorization and self-categorization that arose in the $20^{\text {th }}-21^{\text {st }}$ centuries. These theories revealed the specifics of social identity as self-categorization of a more complex (inclusive) level.

The main contribution to the development of the theory was made by J. Turner (Turner et al., 1994; Turner, Onorato, 1998; Turner, 1999), S.A. Haslam (Haslam et al., 1996; Haslam, 1997, 2001), and others. The scientists focused on the analysis of the functioning of categorization processes in social perception and interaction between groups. Based on the basic theoretical principles of cognitive psychology, J. Turner and his colleagues determined that the theory of self-categorization can allow us to see the qualification of "I" at different levels of abstraction (Turner, Oakes, 1986). People can qualify themselves as a single "I" (personal identity) or as a more complex "we" (social identity). Social identity occurs when "I" is cognitively grouped as identical and interchangeable with other incentives in this category. In intergroup phenomena, it is precisely this type of self-categorization that lies at the core. The complexity of social identity is determined by increasing the level of abstraction: the average level of abstraction corresponds to the social "I", where the perceiving self is classified as "we" compared to a noticeable outgroup (them); the highest level of abstraction is presented by us, people, where animals or other non-humans are a significant outgroup. A change in self-categorization arises with the 
expansion of the comparative context and at a higher level of abstraction. In other words, the function of the comparative context plays a role both in personal identification (when an individual identifies himself when comparing with another person) and in the case of social identification with expanding the comparative context, when, for example, a group of women distinguish their own in-group from the external group of men. Thus, the main social categories form the basis of the social world enriched with meaning. The resulting increase in social content allows a perceiver to interact with others with greater confidence and ease.

Scientists conceptually analyse social identification for psychological mechanisms and processes, their consequences, motivation for categorization, change of social identity during the life of an individual, and begin to develop the concept of "social identity" as multiple, having various forms of identity and, in many ways, forming personal and, at the same time, collective identity (Rothbart, John, 1985, Deaux, 1996; Macrae et al., 1995). As an example, it is possible to cite the study of scientists Miles Hewstone, Mir Rabiul Islam, and Charles M. Judd who presented six models of cross-categorization and intergroup relations (Hewstone et al., 1993). In two experiments, a hypothesis of the existence of intergroup discrimination in social categorization was tested. It was concluded that the following dependent primary variables have additive effects among groups of Hindus and Muslims: "religion" (in interaction with the categories "country" and "language") and "nationality". Regarding SIT, scientists note that the results of their research indicate that positive identity can be achieved in terms of ordering into a hierarchy through the intragroup favouritism or group retreat. Social identity is an additive model in which, at the intersection of categories, social categorization does not perform the functions of systematizing and simplifying the social environment, but becomes a complex social identity. The analysis of the models made it possible to determine the difficulties of studying situations of cross-categorization, especially when the experiment takes place outside of laboratory conditions.
In the late 1980's and early 1990's, there was a realization that the study of social identity could not be fully based on a minimal group paradigm. In the 1990's, researchers have created new ways to manipulate the same variables using real social categories. The result of this process is that the original Tajfel and Turner's hypotheses about social and structural variables have been generalized, clarified and expanded. Thus, the concepts of "general identity" (Prentice et al., 1994), "disidentification" (Dukerich et al., 1998; Elsbach, 1999; Ashforth et al., 2001), "multiple categorization" (Stangor et al., 1992), "cross categorization" (Urban, Miller, 1998; Crisp et al., 1999) have been developed and introduced; the levels of collective identity and self-presentation (Brewer, Gardner, 1996), individual and group levels (Brown, 2000, 2004; Brewer, 2010) have been studied. The analysis of forms of social identity is a subject of a collective work by Brian Lickel, David L. Hamilton, Amy Lewis, Steven J. Sherman, Grazyna Wieczorkowska, A. Neville Uhles (Lickel et al., 2000), which presents a classification of social groups and shows how forms of social identity can vary in a degree of value in connection with the level of satisfaction of the individual's needs. Scientists especially note that ethnic identity stands apart in categorization, as representatives of ethnic minorities highly value their participation in an ethnic group.

We also should note a special contribution to the development of the concept of "complex identity" made by sociology professor Richard Jenkins, who published the book titled "Social Identity" in 1996. In this book, the scientist expressed the need to combine theoretical and empirical research works for the future development of sociology: "in the future of sociology, which I try to imagine, we need to reconsider the concepts of "society," "social structure," "social groups" that were adopted without reflection... "finally, the last area that awaits theoretical work: we need to get used to the unpredictability and probabilistic aspects of human life. Both in theory and in essence, we are searching for patterns: this is the foundation of a scientific enterprise (and the basic principle of human cognition). But in 
the human world, perhaps, there is more room for probabilistic events than we think, even more than in the natural world. The problem here is that we are expected (by others and ourselves) to discover patterns, preferably with some predictive power" (Jenkins, 2014). In his theory, R. Jenkins reveals the definition of the complexity of identification as a dual process: external categorization and internal self-identification. The author writes that identity and identification are undoubtedly interconnected, have a meaning in everyday life, affect everyday situations and real human experience. As a starting point for defining the concept of "identity," Jenkins writes that "it is a human ability, rooted in the language, to know "who is who' and, therefore, 'what is what.' Identification arises only in the process of relations between individuals or groups, when the result is an identity (emergent), individual or collective. Internally, an emergent can be categorized into a hierarchy or scale of preference, ambivalence, hostility, competition, partnership and cooperation, and so on. From this perspective, identification and behavioural motives may seem related. However, the classification models of 'I' and 'others' are multidimensional, they can hardly be internally consistent and be easily compared with each other. The hierarchies of collective identification can be combined with hierarchies of individual identification, which means that full interaction can be given meaning. Taken together, these provisions indicate that categorical imperatives are unlikely to be sufficient guidance and that the ability to distinguish others in a subtle and clear way is a daily necessity. Later, in his speech when receiving the title of Honorary Professor of the University (Jenkins, 2015), R. Jenkins speaks of an urgent need for empirical studies, in which the objective intersections of sociology with many disciplines (social psychology, cultural studies, social anthropology, social politics, social history) will help to participate "in observing the ups and downs of everyday life, in the detailed documentation of behavioural patterns of average radius of coverage, in identifying and interpreting emerging trends in the institutionalization processes and their outcomes" (Jenkins, 2015: 19).

\section{Research results}

In the early 2000's, an interdisciplinary approach has been developed to study complex social identities, which synthesizes developments based on social identity and self-categorization theories (Brown, 2000; Haslam et al., 2010). Social and psychosocial factors influence the way an individual integrates many social identities: with a weak intersection of in-groups, great psychological stress arises because the individual is aware of the difference in his groups (Barreto, Gardner, 2003). However, minimal intersection reveals a high degree of complexity of social identity, showing not only that people are able to manage their multi-layered and multi-level identity, but also reflecting their experience and perception of sociocultural factors occurring in their daily lives (Ferguson, 2006). Studies on the intersection of the categories of multiple groups (Crisp et al., 2001) revealed changes in traditional stereotypes (for example, the impossibility of including female groups in professional areas) and recorded the emergence of new hybrid identities that could affect perception and individual well-being (Cross et al., 2003; Crisp et al., 2006).

In 2002, scientists Sonia Roccas and Marilynn Brewer, using a structurally functional approach, proposed a concept of the complexity of social identity, which disclosed the phenomenon of the subjective representation of an individual about the interconnections of his multiple group identities, each of which has a certain degree of coincidence (Roccas, Brewer, 2002). The scientific hypothesis suggests that the level of complexity of social identity increases when combined from similar and intersecting to non-similar and non-intersecting identifications. The complexity of social identity is formed when an individual consciously differentiates and integrates multiple group identities, recognizing their difference in functional roles. The choice of simple (intra-group) or complex (inter-group) social identity depends on personal value priorities and tolerance for members of an external group or groups. Not long before the concept emerged, Marilynn Brewer (1996) suggested that different levels of identity represent different perspectives for the 
interpretation of social reality, and the theory of collective identity becomes a comprehensive theory for understanding variability both within and between people. One of the key needs of a person is the need for identity - to define oneself in contact with others. The phenomenon of social identity manifests itself in most people in the simultaneous belonging of an individual to several social groups. At the turn of the $20^{\text {th }}-21^{\text {st }}$ centuries, society has globalized and allowed individuals to cross geographic, cultural, and social boundaries, to express themselves through wide and variable membership in various groups and social categories (Crisp, 2001).

S. Roccas and M. Brewer investigate two problems at once: the nature of relations between the numerous intragroup identities of a particular person, and the influence of multiple social identities on intergroup relations as a whole. For an individual, understanding the structure of identity is very important, since ideas about their groups affect not only self-esteem, but also the nature of the relations between them. Scientists dwell in detail on the processes by which group membership can contribute to the complexity of social identity.

A complex social identity is formed from multidisciplinary participation in target groups characterized in the human mind by interpersonal relationships and personal interactions between group members. The authors propose four alternative structures for multiple intra-group representations. Two conditional identities of two social categories are taken as a basis and the forms structurally formed from the inclusion or exclusion of other people as members of a subjective group are shown.

The first structure is called the "intersection" of several group memberships: when an individual constructs a single idea of his "social self" at the intersection of several group memberships. This is a single unique construction of social identity with stable characteristics, built on several foundations of group identifications. The binding factors in the structure are the minimum of differences, the absence of conflict, stereotypy, unambiguity, simplicity and unity, a clear understanding of the boundaries of the in-group and unmixing with other groups. The model of intersection of the intragroup representation arises in the process of joining and similarity, in which the joining of two group identities constitutes the in-group of the perceiver.

The second structure is referred to as "dominance," when one social identity is priority over other functional roles of the individual, but on the basis of which this individual identifies himself with the primary (main) group. When an individual classifies himself and others as one large group, the intragroup category can be identified with the prototype of the group (a representative, a pattern). Other alternative social identities are embedded in the group's primary identification ("as sources of intragroup variation"), but do not apply to those outside the group (Roccas, Brewer, 2002: 90 ). The individual conceptualizes his primary social identities and groups on a professional basis, and identifications in other categories are subordinated to the primary category as variative behaviour. This structure is more complex than the first one, since it has fragmentation of social identities within one dominant (primary) one.

The third structure operates with separate social identities, where one is a source for the social "I" and the others exist relatively separately, and are activated in different contexts and situations. For example, in the office team work, only professional identity is important, while the rest (gender, ethnic, religious, cultural) are not involved for group identity. However, in a different context, for example, in a family circle, cultural and religious identity is activated. Thus, multiple identities are as if divided and differentiated, exist isolated from each other and are actualized (switched) under certain conditions. The "separate" structure operates according to an additive evaluation scheme for other people depending on their membership in several groups.

The last, fourth structure is referred to as "merging," in which the integration of all multiple groups within one category of social identity occurs. The authors of the concept note that the complexity of this structure is that "identification within a group extends to those who share any important social category of 
membership - social identity - the sum of one united group identification." All identifications are relevant and interact with each other on an equal basis as a combination of social identities. Inside the structure, various components and characteristics are integrated, in order to create a complex form of united identity within the group. The result is a variety of social identities, in which a single categorical separation between people disappears (for example, to evaluate them from the point of view of a particular categorical identity). The authors note that the more numerous an individual's social identity is, the more difficult it becomes to define his in-group: in any dimension, there is no clear distinctions between in-groups and out-groups due to their equivalent assessment.

The concept of S. Roccas and M. Brewer shows that the difficulty of differentiating multiple social identities within one group forms a more positive self-determination in an individual than in a person who supports only one membership in a group. Four structures have different ways to resolve inconsistencies between incompatible beliefs or attitudes. In the "intersection" structure, a cognitive form of differentiation functions: when selected beliefs are combined to create a crossed identity and are separated from other categorical contradictions. In the "dominance", identities are combined to strengthen the dominant one. In the "separate" structure, identities are cut off from each other, like sector isolation in cognitive structures. In the "merging" structure, multiple identities are not differentiated, but strive to become an integral, a guiding principle of which is combination of incompatible knowledge. Typically, an individual supporting a single, united presentation of his many social identities may resort to intersection, dominance or separation during periods of stress or uncertainty. Thus, the subjective presentation of multiple identities can reflect both individual differences and situational factors. Some people may be predisposed to the high complexity of social identity. For such people, the integrative difficulty in thinking about multiple intragroup identities can become automatic, requiring relatively little conscious efforts or cognitive resources. However, it can be ex- pected that in most cases, the complexity of social identity varies depending on the person's current motivation to think of their several intra-group identities and use cognitive resources to combine these identities in a complex way. Thus, in the theory of the complexity of social identity, S. Roccas and M. Brewer argue that multiple group identities differ in the degree of coincidence between groups, and this depends on subjective perceptions. A large degree of non-overlapping groups (high SIC) is associated with more favourable intergroup relations, however this form is dependent on many social and psychological factors that limit its development (high need for closure, desire to maintain the status quo, high stress or cognitive pressure, life in a monocultural or a stratified society). However, a high degree of SIC shows the ability of people to identify (have more opportunities to derive their own benefits, satisfy their needs) from different groups in different ways than people with a simple form of identity (low SIC), which limits the nature of identification with different groups and reveals more invariant models of identification. Another aspect in understanding the nature of multiple identities is the ability to combine multiple aspects of personality, to direct one's own actions and attention in connection with a change in context. Today, in the field of science, the theoretical approach of Roccas and Brewer offers great opportunities for understanding the psychology of intersectional identities.

The concept of the complexity of social identity proposed by Roccas and Brewer continues to play an influential role in subsequent studies of complex identity. Complex forms are analysed for the occurrence of intergroup threats (Brewer, Pierce, 2005; Schmid et al., 2009), or vice versa, are interpreted as a source of sustainability and well-being (Douglas, 2012; Jones et al., 2012), which contributes to the formation of a multifaceted and unique self-esteem, greater accessibility to social support and well-being (Jetten et al., 2015). Recognition of complex forms of identity provides the basis for reducing intergroup differentiation and / or discrimination. The combination of the multiple and higher categories (for example, when revealing a common human identity) reduces 
dehumanization and increases the sense of connection with other people, helps to build favourable intergroup relations. A positive intergroup attitude and equity assessment are becoming important factors in supporting social policy in a multicultural world. The perception of a complex identity provides an additional opportunity to be included in a broad social identity, minimizing negative stereotypes, and thereby allowing others to recognize the multifaceted social identities of building less biased relationships and more positive social interactions. The positive influence of multiple identities occurs in the process of switching between different social identities in accordance with the current context, needs and goals. From a larger number of identities, the chances are that one of these identities will be evaluated in a given social context. This process can be called "adaptive identity." Since multiple identities represent greater opportunities for flexible self-determination, they provide individuals with more opportunities to achieve optimal distinctness (balancing between the need to assimilate and differ from others). The ability to switch their identities allows individuals to emphasize their most adaptive identity, while minimizing the disadvantageous or less relevant identities, and thereby prevent stereotypical threats against themselves. Complex identity allows one to be flexible with respect to others, and therefore it seems promising to develop skills related to repeated recognition of identity and self-determination in adults and children, which they can maintain throughout their lives. The ability to recognize and evaluate their multiple identities at an early stage in the development of children will determine the prospects for their development. It is especially necessary to develop this skill in modern times - the time of immigration processes, mixed and multicultural identities. The positive resources of multiple identities built at the intersection of other identities open up in an adequate perception of other people, positive intergroup relations, and the universality of human experience.

In the last decade, the phenomenon of complex identity has been studied as a factor in improving emotional well-being (Binning et al., 2009; Jetten et al., 2010), mental and phys- ical stability (Jones, Jetten, 2011), improving the quality of life and survival (Haslam et al., 2008), as one of the conditions of stress and social adaptation (Iyer et al., 2009). The relevance of the study of the phenomenon of complex identity for scientists is in the fact that multiple identity as identification with several social groups makes people stronger in their social world and provides them with multiple connections with other people as similar to each other (Haslam et al., 2008; Jetten et al., 2012). In this regard, multiple social ties are of particular importance and form social support, thereby providing resources for self-development, choice of values, attitudes, and behaviour (e.g., Jetten et al., 2015; Chang et al., 2016; Steffens et al., 2016). The more complex the identity, the higher the level of individual well-being: multiple identities contribute to individual well-being through perceived expression of identity and social support, as well as compatibility of identity and social integration (Sønderlund et al., 2017).

The discussion about the nature of the complexity of social identity in modern Russian research works unfolded at the turn of the $20^{\text {th }}-21^{\text {st }}$ centuries, when questions about the specifics of the formation of new social identities in the process of ongoing socio-economic changes began to be raised in Russian science (Tronevskaia, 2015). Russian sociologist V.A. Iadov (Iadov, 1995) was one of the first to develop the concept of "human self-identification" as a process of realizing individual social identity in a social-group space: a conscious sense of belonging to various social communities provides a social and socio-psychological function both in the assessment of the group and in self-esteem. The scientist especially emphasizes the need for an interdisciplinary study of the phenomenon of identity at the border of the sciences of psychology and sociology, since the study of the psychological process of identification and the social mechanism of self-determination of an individual in diverse societies allows one to obtain and interpret data in a single socio-psychological approach. A focus on an interdisciplinary approach allowed Russian scientists studying the deep processes of social identity to conceptually expand 
the phenomenon of complex identity with the concept of "organizational identification" (Lipatov, Lovakov, 2010; Uspenskaia, 2017; Nesmeianova, 2017, Nesmeianova, Lipatov; 2017; Nesmeianova, 2018). Types of organizational identification are described by O.N. Burmistrova (Burmistrova, 2009), who pays attention to concepts that have not yet been developed in social psychology, such as "organizational disidentification," "neutral identification" and "dual identification." The problem of the complexity of social identity, defined by S. Roccas and $\mathrm{M}$. Brewer, is used by Russian social psychologists in O.E. Khukhlaev and M.A. Khait in a primary empirical study (Khukhlaev, Khait, 2012). In 2014, Maria Khait published the results of a cross-cultural study of the interconnection between the complexity of social identity (based on an analysis of the attitude to the situation of uncertainty in Russia and Italy). The author confirms her hypothesis that the studied interconnection between the attitude to uncertainty and the level of complexity of social identity is a cultural universal. The interrelation between the levels of group, micro-group and interpersonal identity was identified by A.V. Sidorenkov and V.A. Dorofeev (Sidorenkov, Dorofeev, 2016). The authors conclude that the levels of identity form a certain hierarchy (group, subgroup, individual), they are interconnected (complete and linear, weak or incomplete), and have different degrees of severity. In this connection, the authors proposed two more additional levels: personal and organizational identity, in order to understand the connection between the five levels of identity.

\section{Conclusion}

The concept of "complex identity" is complex and inextricably linked with the determination of the nature of the forms of individual and social identity. In the last third of the $20^{\text {th }}$ century, the concept of "social identity" emerged in connection with the historically necessary analysis of intergroup relations and was unchanged until the beginning of the $21^{\text {st }}$ century in the field of social sciences. The theoretical developments of G. Tajfel, J. Turner, R. Jackinson, S. Haslam became the basis for the subsequent interdisciplinary study of the phenomenon of identity and its complex nature that changes in the real world. At the beginning of the $21^{\text {st }}$ century, in connection with the manifestation of the dynamics of globalization processes that accelerated the interaction of the social world, scientists focused more on studying the process of intergroup relations as a longterm one, consisting of contacts and the results of interaction between different social groups. The concept of S. Roccas and M. Brewer made it possible to reveal the concept of "complex identity" as a phenomenon having the structure and forms of identification intersections, thereby providing a powerful methodological tool for studying the specifics of identity forms and the process of constructing identity in an individual and group sense, on interpersonal and intergroup levels where a huge layer of interaction aspects is revealed.

The formation of the concept of "complex identity" in modern humanities has been rapid and diverse. However, it is one of the most scientifically discussed topics at the conceptual, methodological and applied levels. The phenomenon of complex identity has a wide subject field that is far from unification and from the emergence of a unified socio-psychological theory of identity (Côté, Levine, 2014). One cannot disagree with this statement, since it is possible to discover the nature of the phenomenon only in the realities of the relationship between a person and society, and therefore the development of the theory of identity in the spirit of classical discipline is impossible. The multiplicity of approaches to the interpretation of identity, developing only into a complex invariant of interdisciplinary study, should be transformed into conceptual and methodological specifics of the most complex forms of the phenomenon of identity.

\section{References}

Ashforth, B.E., Mael, F. (1989). Social identity theory and the organization. In Academy of management review, 14 (1), 20-39. 
Ashforth, B.E., Johnson, S.A., Hogg, M., \& Terry, D. (2001). Which hat to wear. Social identity processes in organizational contexts, 32-48.

Barreto, M., Ellemers, N. (2003). The effects of being categorised: The interplay between internal and external social identities. In European review of social psychology, 14 (1), 139-170.

Binning, K.R. et al. (2009). The interpretation of multiracial status and its relation to social engagement and psychological well-being. In Journal of Social Issues, 65 (1), 35-49.

Brewer, M.B., Gardner, W. (1996). Who is this "we"? Levels of collective identity and self-representation. In Journal of Personality and Social Psychology, 71, 83-93.

Brewer, M.B., Pierce, K.P. (2005). Social identity complexity and outgroup tolerance. In Personality and Social Psychology Bulletin, 31 (3), 428-437.

Brewer, M.B. (2010). Social identity complexity and acceptance of diversity.

Brown, R. (2000). Social identity theory: Past achievements, current problems and future challenges. In European journal of social psychology, 30 (6), 745-778.

Brown, B.A. (2004). Discursive identity: Assimilation into the culture of science and its implications for minority students. In Journal of Research in Science Teaching: The Official Journal of the National Association for Research in Science Teaching, 41(8), 810-834.

Burmistrova, O.N. (2009). Vidy organizatsionnoi identifikatsii [Types of organizational identification]. In Uchenyye zapiski Rossiiskogo gosudarstvennogo sotsial'nogo universiteta [Scientific notes of the Russian State Social University], 11, 252-255.

Campbell, D.T. (1965). Ethnocentric and other altruistic motives. In Nebraska symposium on motivation, 13, 283-311.

Chang, M.X.L. et al. (2016). The more (social group memberships), the merrier: Is this the case for Asians? In Frontiers in psychology, 7, 1001.

Côté, J.E., Levine, C.G. (2014). Identity, formation, agency, and culture: A social psychological synthesis. Psychology Press, $268 \mathrm{p}$.

Crisp, R.J., Hewstone, M. (1999). Differential evaluation of crossed category groups: Patterns, processes, and reducing intergroup bias. In Group Processes \& Intergroup Relations, 2 (4), 307-333.

Crisp, R.J., Hewstone, M., Rubin, M. (2001). Does multiple categorization reduce intergroup bias? In Personality and social psychology bulletin, 27 (1), 76-89.

Crisp, R.J., Hewstone, M. (2007). Multiple social categorization. In Advances in experimental social psychology, 39, 163-254.

Crisp, R.J., Stone, C.H., \& Hall, N.R. (2006). Recategorization and subgroup identification: Predicting and preventing threats from common ingroups. In Personality and Social Psychology Bulletin, 32(2), 230-243.

Cross, S.E., Gore, J.S., Morris, M.L. (2003). The relational-interdependent self-construal, self-concept consistency, and well-being. In Journal of personality and social psychology, 85 (5), 933.

Deaux, K. (1996). Social identification.

Douglas, J.M. (2012). "Social linkage, self-concept, and well-being after severetraumatic brain injury". In The Social Cure: Identity, Health and Well-Being, eds J. Jetten, C. Haslam, and S.A. Haslam (New York, NY: Psychology Press), 237-254.

Dukerich, J.M., Roderick, K., Judi, L.P. (1998). The dark side of organizational identification. In Identity in organizations: Building theory through conversations, Sage, 245-256.

Elsbach, K.D. (1999). An expanded model of organizational identification.

Ferguson, A. (2006). Intersections of identity: Navigating the complexities. Forum on public policy: A journal of the Oxford Round Table. Available at: https://www.questia.com/library/journal/1G1-244026564/ intersections-of-identity-navigating-the-complexities

Haslam, A., Oakes, P., Turner, J., McGarty, C. (1996). Sorrentino, Richard; Higgins, Edward, eds. Social identity, self-categorization, and the perceived homogeneity of ingroups and outgroups: The interaction between social motivation and cognition. In Handbook of Motivation and Cognition: The Interpersonal Context, Handbook of Motivation and Cognition, 3, 182-222. 
Haslam, S.A. Spears, R., Oakes, P.J., Ellemers, N., et al. (1997). Stereotyping and social influence: Foundations of stereotype consensus. In The Social Psychology of Stereotyping and Group Life, 119-143.

Haslam, A.S. (2001). Psychology in Organizations. London, SAGE Publications

Haslam, C., Holme, A., Haslam, S.A., Iyer, A., Jetten, J., Williams, W.H. (2008). Maintaining group memberships: Social identity continuity predicts well-being after stroke. In Neuropsychological rehabilitation, 18 (5-6), 671-691.

Haslam, S.A., Ellemers, N., Reicher, S.D., Reynolds, K.J. Schmitt, M.T. (2010). The social identity perspective today: The impact of its defining ideas. In Rediscovering social identity: Key readings (341-356).

Haslam, C., Jetten, J., Alexander, S.H. (2012). The social cure: Identity, health and well-being. Psychology press, 237-254.

Haslam, S.A., Oakes, P.J., Turner, J.C., McGarty, C. (1995). Social categorization and group homogeneity: Changes in the perceived applicability of stereotype content as a function of comparative context and trait favourableness. In British Journal of Social Psychology, 34 (2), 139-160.

Haslam, S.A., Oakes, P.J., Reynolds, K.J., \& Turner, J.C. (1999). Social identity salience and the emergence of stereotype consensus. In Personality and Social Psychology Bulletin, 25(7), 809-818.

Haslam, S.A. (2004). Psychology in organizations. Sage, 336 p.

Haslam, S.A., Reicher, S.D., Platow, M.J. (2010). The new psychology of leadership: Identity, influence and power. Psychology Press, $296 \mathrm{p}$.

Hewstone, M., Islam, M.R., Judd, C.M. (1993). Models of crossed categorization and intergroup relations. In Journal of Personality and Social Psychology, 64 (5), 779.

Hornsey, M.J. (2008). Social identity theory and self-categorization theory: A historical review. In Social and personality psychology compass, 2 (1), 204-222.

Iadov, V.A. (1995). Sotsial'nye i sotsial'no-psikhologicheskie mekhanizmy formirovaniia sotsial'noy identichnosti lichnosti [Social and socio-psychological mechanisms of the formation of social identity of a person]. In Mir Rossii [World of Russia], 3 (4), 158-181.

Iyer, A., Jetten, J., Tsivrikos, D., Postmes, T., Haslam, S. A. (2009). The more (and the more compatible) the merrier: Multiple group memberships and identity compatibility as predictors of adjustment after life transitions. In British Journal of Social Psychology, 48 (4), 707-733.

Jenkins, R. (2015). Chto zhdet sotsiologiiu: vymiranie, zastoi ili evoliutsiia? [What awaits sociology: extinction, stagnation or evolution?]. In Sotsiologicheskie issledovaniia [Sociological studies], 3, 11-21.

Jenkins, R. (2014). Social identity. Routledge, 264 p.

Jetten, J., Haslam, C., Pugliese, C., Tonks, J., Haslam, S.A. (2010). Declining autobiographical memory and the loss of identity: Effects on well-being. In Journal of clinical and experimental neuropsychology, 32 (4), 408-416.

Jetten, J., Branscombe, N.R., Haslam, S.A., Haslam, C., Cruwys, T., Jones, J.M., Thai, A. (2015). Having a lot of a good thing: Multiple important group memberships as a source of self-esteem. In PloS one, 10 (5), 1-29.

Jetten, J., Branscombe, N.R., Haslam, S.A., Haslam, C., Cruwys, T., Jones, J.M., et al. (2015). Having a lot of a good thing: multiple important group memberships as a source of self-esteem. PLoS ONE 10:e0124609. DOI: 10.1371/ journal.pone.0124609

Jones, J.M., Jetten, J., Haslam, S.A., Williams, W.H. (2012). Deciding to disclose: The importance of maintaining social relationships for well-being after acquired brain injury. In The social cure: Identity, health and well-being, 255-271.

Jones, J.M., Jetten, J. (2011). Recovering from strain and enduring pain: Multiple group memberships promote resilience in the face of physical challenges. In Social Psychological and Personality Science, 2 (3), 239-244.

Khukhlaev, O.E., Khait, M.A. (2012). Slozhnost' sotsial'noi identichnosti: kontseptsiia S. Rokkas i M. Briuer [The complexity of social identity: the concept of S. Roccas and M. Brewer]. In Sotsial'naia psikhologiia i obshchestvo [Social Psychology and Society], 3, 16-26. 
Lickel, B., Hamilton, D.L., Wieczorkowska, G., Lewis, A., Sherman, S.J., Uhles, A.N. (2000). Varieties of groups and the perception of group entitativity. In Journal of Personality and Social Psychology, 78, 223-246.

Lipatov, S.A., Lovakov, A.V. (2010). Sovremennye issledovaniia organizatsionnoi identifikatsii v zarubezhnoi psikhologii [Modern studies of organizational identification in foreign psychology]. In Natsional'nyi psikhologicheskii zhurnal [National Psychological Journal], 1 (3), 70-75.

Macrae C.N., Bodenhausen, G.V., Milne, A.B. (1995). The dissection of selection in person perception: inhibitory processes in social stereotyping. In Journal of personality and social psychology, 69 (3), 397-407.

Nesmeianova, R.K. (2017). Sub"ektivnoe predstavlenie o korporativnoi kul'ture i organizatsionnaia identifikatsiia: osobennosti vzaimosviazi [Subjective idea of corporate culture and organizational identification: features of the relationship]. In Vestnik Moskovskogo universiteta, Seriia 14. Psikhologiia [Moscow University Herald, Series 14. Psychology], 2017, 1, 88-104.

Nesmeianova, R.K., Lipatov, S.A. (2018). Aktual'nyye tendentsii issledovaniia organizatsionnoi identifikatsii $\mathrm{v}$ zarubezhnoi psikhologii [Actual trends in the study of organizational identification in foreign psychology]. In Chelovecheskii kapital [Human capital], 1, 60-72.

Nesmeianova, R.K., Lipatov, S.A. (2017). Vzaimosviaz' vospriiatiia i privlekatel'nosti korporativnoi kul'tury s organizatsionnoi identifikatsiei sotrudnikov [Interrelation of perception and attractiveness of corporate culture with organizational identification of employees]. In Organizatsionnaia psikhologiia [Organizational Psychology], 7 (3), 67-84.

Onorato, R.S., Turner J.C. (2004). Fluidity in the self-concept: the shift from personal to social identity. In European journal of social psychology, 34 (3), 257-278.

Prentice, D.A., Miller, D.T., Lightdale, J.R. (1994). Asymmetries in attachments to groups and to their members: Distinguishing between common-identity and common-bond groups. In Personality and Social Psychology Bulletin, 20 (5), 484-493.

Reynolds, K.J., Turner, J.C. (2006). Individuality and the prejudiced personality. In European review of social psychology, 17 (1), 233-270.

Roccas, S., Brewer, M.B. (2002). Social identity complexity. In Personality and social psychology review, 6 (2), 88-106.

Rothbart, M., John, O.P. (1985). Social categorization and behavioural episodes: A cognitive analysis of the effects of intergroup contact. In Journal of Social Issues, 41 (3), 81-104.

Schmid, K., Hewstone, M., Tausch, N., Cairns, E., Hughes, J. (2009). Antecedents and consequences of social identity complexity: Intergroup contact, distinctiveness threat, and outgroup attitudes. In Personality and Social Psychology Bulletin, 35(8), 1085-1098.

Sidorenkov, A.V., Dorofeev, V.A. (2016). Sootnoshenie gruppovoi, mikrogruppovoi i mezhlichnostnoi identichnosti rabotnikov v proizvodstvennykh gruppakh [Correlation of group, micro-group and interpersonal identities of workers in production groups]. In Sotsial'naia psikhologiia i obshchestvo [Social Psychology and Society], 7 (3), 60-75.

Sønderlund, A.L., Morton, T.A., Ryan, M.K. (2017). Multiple group membership and well-being: Is there always strength in numbers? In Frontiers in psychology, 8, 1038.

Stangor, C., Lynch, L., Duan, C., Glass, B. (1992). Categorization of individuals on the basis of multiple social features. In Journal of Personality and Social Psychology, 62, 207-218.

Steffens, N.K., Jetten, J., Haslam, C., Cruwys, T., \& Haslam, S.A. (2016). Multiple social identities enhance health post-retirement because they are a basis for giving social support. In Frontiers in psychology, 7, 1519.

Tajfel, H. (1974). Social identity and intergroup behaviour. In Information (International Social Science Council), 13(2), 65-93.

Tajfel, H.E. (1978). Differentiation between social groups: Studies in the social psychology of intergroup relations. Academic Press.

Tajfel, H. (1982). Social identity and intergroup relations. Cambridge and Paris. 546 p. 
Tajfel, H., Turner, J.C., Austin, W.G., \& Worchel, S. (1979). An integrative theory of intergroup confict. Organizational identity: A reader, 56, 65.

Tetlock, P.E. (1986). A value pluralism model of ideological reasoning. In Journal of Personality and Social Psychology, 50, 819-827.

Tetlock, P.E. (1983). Accountability and complexity of thought. In Journal of Personality and Social Psychology, 45, 74-83.

Tronevskaia, M.A. (2015). Transformatsiia sotsial'noi identichnosti v usloviiakh krizisa postmodernistskogo obshchestva i kul'tury [The transformation of social identity in a crisis of postmodern society and culture]. In Teoriia i praktika obshchestvennogo razvitiia [Theory and practice of social development], 3 , 34-37.

Turner, J.C., Tajfel, H. (1986). The social identity theory of intergroup behaviour. In Psychology of intergroup relations, 5, 7-24.

Turner, J.C., Hogg, M.A., Oakes, P.J., Reicher, S.D. \& Wetherell, M.S. (1987). Rediscovering the social group: A self-categorization theory. Oxford: Blackwell.

Turner, J.C., Oakes, P.J., Haslam, S.A., McGarty, C. (1994). Self and collective: Cognition and social context. In Personality and social psychology bulletin, 20 (5), 454-463.

Turner, J.C. (1999). Some current issues in research on social identity and self-categorization theories. In Social identity: Context, commitment, content, 3 (1), 6-34.

Turner, J.C., Hogg, M.A., Oakes, P.J., Reicher, S.D., Wetherell, M.S. (1987). Rediscovering the social group: A self-categorization theory. Oxford, England: Basil Blackwell, 399-417.

Turner, J.C., Oakes, P.J. (1986). The significance of the social identity concept for social psychology with reference to individualism, interactionism and social influence. In British Journal of Social Psychology, 25 (3), 237-252.

Turner, J.C., Onorato, R.S. (1998). Social identity, personality, and the self-concept: A self-categorization perspective. In The Psychology of the Social Self (1).

Urban, L.M., Miller, N. (1998). A theoretical analysis of crossed categorization effects: A meta-analysis. In Journal of Personality and Social Psychology, 74 (4), 894.

Uspenskaia, O.A. (2017). Urovni formirovaniia organizatsionnoi identichnosti sotrudnikov [Levels of Formation of Organizational Identity of Employees]. In Novaia nauka: Opyt, traditsii, innovatsii [New Science: Experience, Traditions, Innovations], 3 (4), 81-85. 


\title{
История исследований сложной идентичности
}

\section{Ю.С. Замараева, Н.П. Копцева}

Сибирский федеральный университет

Российская Федераџия, Красноярск

\begin{abstract}
Аннотация. В статье раскрыта концептуальная проблематика формирования понятия «сложная идентичность» в современных гуманитарных науках на материале анализа зарубежных и отечественных исследований. В научной истории концептуальное определение понятия состоялось в последней трети XX столетия в социологии и социальной психологии, однако с начала XXI века свое прикладное развитие получило благодаря междисциплинарным исследованиям, позволившим ученым выявлять сложные формы идентичности в условиях динамично развивающегося мира. В начале XXI века возрос интерес к идентичности как культурной проблеме и обнаружилась необходимость ее изучения в контексте современной культуры и межкультурных отношений. Культурологическая проблематика позволяет соединить существующие представления в концептуальное определение понятия «сложная идентичность» и выстроить приоритеты исследования в соответствии с современными социальнокультурными отношениями.
\end{abstract}

Ключевые слова: теория социальной идентичности, сложная идентичность, природа сложности социальной идентичности.

Научная специальность: 24.00.01 - теория и история культуры. 